\title{
Research on the Potential of Medicinal Plant Resources under the Conditions of the Southern Original Plants
}

\author{
Tileumuratova B.A. ${ }^{1}$, Mambetullaeva S.M. ${ }^{2}$ \\ ${ }^{1}$ Nukus State Pedagogical Institute \\ ${ }^{2}$ Karakalpak Scientific Research Institute of Natural Sciences
}

\begin{abstract}
Data on resources of the herbs growing in the territory Priaralye are provided in article. It is noted that in the territory of Karakalpakstan grows 360 types of the herbs relating to 212 childbirth from 68 families. In other words, more than $37 \%$ of all plants of Karakalpakstan are medicinal. From them 48 types belong to cultural plants. Distribution of herbs on natural areas Priaral quite unevenly that is explained by distinction of ecological conditions of areas and ecological types of plants.
\end{abstract}

Keywords: Priaralye, medicinal plants, ecological conditions, resources, stocks of raw materials, potential

\section{Introduction}

All over the world, the progressive impact of anthropogenic factors on the state of the natural environment leads to the transformation of the vegetation cover, which plays a significant role in the biosphere as a whole. Vegetation cover has an important key criterion in the national economy of various countries of the world. One of the priority measures in the ecological respect are the protection, reproduction and rational use of natural resources, which can make a great contribution to the spread of economically valuable, including medicinal plant species. At the same time, they are the main foundation for forecasting the trend dynamics of the ecological situation in various regions of our planet.

In the Aral Sea region, medicinal plants have been studied quite well. A huge amount of scientific literature is devoted to them. However, even now, interest in them does not disappear, given their unique ability to influence humans. Since ancient times, people have used many plants as medicines [1, 3]. But in recent years, interest in medicinal plants has especially increased in connection with new methods of their use for treatment and methods of studying their characteristics of influence. Of interest is also the change in distribution areas under new environmental conditions $[5,6]$.

At present, it is necessary to study the modern resource potential of medicinal plants growing in the region of the Southern Aral Sea region. Conservation of biodiversity and protection of medicinal plants, as well as their range in extreme environmental conditions, are of particular complexity and one of the main problems in the South Aral Sea region.

\section{Results and discussion}

The identification of medicinal plant resources is directly related to the determination of the natural resource potential of the entire territory. The spatial distribution of medicinal resources is the basis for predicting the rational use of natural resources.As you know, the landscape relief and modern structure of the Amudarya delta was formed under the influence of various factors; the most important are geology, hydrological regime, climatic conditions and anthropogenic factors.

The drying up of the Aral Sea, and with it the Amu Darya delta, regulation of the river flow and reduction of the areas of tugai and reed thickets led to the development of deflation in places where swamping processes prevailed earlier. Aeolian processes are the main relief-forming process prevailing throughout the Aral Sea area and the dried-up part of the sea bottom.

At one time, V.A. Popov (1990, 1999) showed that one of the leading factors of soil pollution and salinity is the hydrogenic and aerogenic migration of salts. The main reason for the deterioration of soils in the delta and floodplain of the Amu Darya is the increased migration of salts $[11,12,13]$. Intensive desertification and salinization of the lower reaches of the Amu Darya takes place. So, according to scientists, for the period 1953-1979. of the last century, out of 630 thousand hectares of hydromorphic (meadow) soils were transformed into a group of desertifying 310 thousand hectares and into salt marshes 140 thousand hectares. As a result of the destruction of organic matter and soil structure, the fertility coefficient (bonitet) on these lands decreased by 20-25 points [2, 9, 10]. In addition, due to soil degradation and the drying up of the sea, the wind carryover of salts and fine earth to the irrigated areas of Karakalpakstan systematically occurs, which has an extremely negative effect on the development of agricultural crops, reducing their productivity, polluting the final product [8].

In soils, the amount of humus decreases, the proportion of sodium and magnesium absorption increases, and the waterphysical properties deteriorate. The area (more than 2 times) of hydromorphic ecosystems of the Aral Sea region has decreased, but the area of xeromorphic and holomorphic geosystems has increased almost 6 times. 
In recent years, such processes as the deterioration of the quality of river water and their evaporation, the settling of a certain amount of dusty salt from the drained bottom, have led to the intensification of secondary soil salinization. Highly saline soils on irrigated lands in Uzbekistan account for almost 60-65 percent, in Turkmenistan 75-80 percent, in Kazakhstan 60-70 percent, in Karakalpakia 70-80 percent of the total area $[3,4,10]$. All this leads to a deterioration in the quality of crop products grown on saline soils and an increase in the general salinity of food products.

Another important factor in the active pollution of the republic's soils is the intensification of agriculture, the main directions of which are the chemicalization of crop production and land reclamation. Large doses of mineral fertilizers have been used in the republic for many years. According to the materials of the Committee for Ecology and Environmental Protection of the Republic of Karakalpakstan, the maximum amount of mineral fertilizers was used in 1995 -124.5 thousand tons, of which 66.3 thousand tons were nitrogen, 38.2 - phosphorus, 20.0 potash. The main part of mineral fertilizers was applied to cotton (80.0 thousand tons) and rice crops (43.0 thousand tons). The total area of application of mineral fertilizers was 331.2 thousand hectares. The greatest load on the soil was observed in Shumanai, Khodjeyli, Amu Darya, Beruniy, and Ellikkala districts, sometimes reaching $1000 \mathrm{~kg} / \mathrm{ha}$, which is six times higher than in Uzbekistan.

In the Aral Sea region, the vegetation cover is very diverse. The flora of the republic is represented by various ecological forms of plants: trees, shrubs and shrubs, semi-shrubs and semi-shrubs, perennial and annual grasses, thorny shrubs, plants with succulent stems and leaves, stemless, leafless plants. Medicinal, fodder, fruit, tanning, dyeing, essential oil, technical, decorative, melliferous and other plants grow here.

The therapeutic effect of many hundreds of types of medicinal plants currently used in scientific and folk medicine is associated with the presence of biologically active substances in them that affect various physiological processes of the human and animal body. These substances are called active ingredients. The most common active substances are alkaloids, glycosides, flavonoids, coumarins, essential oils, tannins, vitamins, etc. Depending on the availability of active substances, plants are used for various groups of diseases [4].

It should be noted that for various reasons, including economic ones, today interest in herbal preparations and plants has reappeared. Plants produce a huge amount of various substances that affect the body, incl. physiologically active substances (PAV), or biologically active substances (BAS). As you know, medicinal plants and phytopreparations obtained from them have a significant advantage over synthetic ones, since they have a longer and milder effect on the body and usually do not accumulate in it $[3,6,7]$.

In recent years, scientists have noted that 360 species of medicinal plants, belonging to 212 genera from 68 families, grow in the territory of Karakalpakstan. In other words, more than $37 \%$ of all plants in Karakalpakstan are medicinal $[1,5]$. Of these, 48 species are classified as cultivated plants. The distribution of medicinal plants in the natural regions of the Aral Sea region is rather uneven, which is explained by the difference in the ecological conditions of the regions and the ecological types of the plants themselves. The main ecological factors of all natural landscapes of the Aral Sea region are climatic (light, moisture, temperature) and edaphic factors (chemical and mechanical composition of the soil, salinity and aridization).

\section{Conclusions}

The ecological range of growth of medicinal plants in the Aral Sea region is very wide, i.e. from submerged plants of reservoirs and lakes to typical desert plants. The analysis showed that 161 species of medicinal plants grow in the Amu Darya delta, and about 66 species of medicinal plants grow on sandy massifs. 85 species of medicinal plants grow on the Ustyurt plateau $[1,2,13]$.

Thus, the expansion of the use of herbal medicines is extremely urgent, economically justified and beneficial. When examining the resources of medicinal plant raw materials, it is necessary to be based on the following aspects: firstly, it is necessary to have information about the biological reserves of raw materials that can be prepared on a certain area of the growing massifs of the medicinal plant; secondly, to have an idea of the operational reserves, i.e. the amount of raw materials that can be procured in a given area of an array of medicinal plants and without undermining the possibility of plant renewal and regeneration of populations.For the successful procurement of wild-growing raw materials, it is necessary, first of all, to study the areas of producing plants, to map the growth of medicinal plants suitable for harvesting, assessing the stocks of raw materials in them, to establish the optimal collection time and mode of operation of thickets. The reserves are determined in two ways: 1) on specific thickets, 2) on key sites, with subsequent extrapolation of the obtained data to the entire area of similar lands within a district, region or area. Determination of stocks for specific medicinal plants is carried out if the necessary cartographic materials are not available, when raw materials are prepared by a brigade method, when stocks of rare plants and plants that do not have a clear phytocenotic confinement are established.

The new results obtained on the distribution in the new ecological conditions of the Aral Sea region will help to use different groups of medicinal plants in a new way.

\section{References}

[1] Бахиев А., Бутов К.Н., Даулетмуратов С Лекарственные растения Каракалпакии.- Ташкент.: ФАН.- 1983.

[2] Бондаренко О.Н. Определитель высших растений Каракалпакии.- Ташкент.: Наука.- 1964.

[3] Гаммерман А.Ф., Кадаев Г.Н., Яценко-Хмелевский А.А. Лекарственные растения (Растенияцелители).- М.: Высшая школа.- 1990.- 542 с.

[4] Гроссгейм А.А. Растительные богатства Кавказа.МОИП.- 1952. 
[5] Даулетмуратов С.Д. Ресурсы лекарственных растений Каракалпакии и их охрана. Нукус, Каракалпакстан.- 1991.- 135 с.

[6] Логвиненко И.Е., Логвиненко Л.А. Лекарственные растения, перспективные для введения в культуру на юге Украины. //Труды Никитского ботанического сада. 2011. Том 133.- с. 104-114.

[7] Турова А.Д., Сапожникова Э.Н. Лекарственные растения и их применение.- М.: Медицина.- 1983.$288 \mathrm{c}$.

[8] Толкачева Г.А. Научно-методические основы мониторинга атмосферных выпадений в Среднеазиатском регионе. - Ташкент. - 2000. 204c.

[9] Новикова Н.М., Мамутов Н.К., Трешкин С.Е. Микроочаговые процессы при рассолении солончаковых почв / // Микроочаговые процессыиндикаторы дестабилизированной среды. М., 2000. - С. 133-139.

[10] Жоллыбеков Б. Трансформация почвенного покрова приморской дельты Амударьи в связи с антропогенным опустыниванем // Проблемы освоения пустынь.- 1987.- №2.- с. 26-33.

[11] Глазовский Н.Ф. Современноесоленакопление в аридных областях.- М.- Наук.- 1987.- 192 с.

[12] Гельдыева Г.В., Будникова Т.И., Медведева Н.Ю. Основные закономерности естественной стабилизации ландшафтов осушенного дна Аральского моря // Вест. КазГУ. - Сер.географ. 1996. - № 3. - С.34-40.

[13] Кабулов С.К. Изменение фитоценоза пустынь в условиях аридизации // Ташкент, 1990.-238 с. 